on day I 3 was better than that obtained on day 15 after mating (94 p. Ioo versus 87 p. Ioo). Besides, the diagnosis of empty sows was well established in two cases out of three. If blood sampling was made on day $\mathbf{1 4}$, the diagnosis was accurate in three sows out of four. When sows entered empty the farrowing pen the farmer could have detected it roo days earlier in I sow out of 2 by determining the blood level of PGF.

\title{
Post weaning growth in piglets
}

\author{
Nicole COUANON, M. Jambou, J. JEHANno et Y. MENGUY * \\ C.T.G.R.E.F., Division de la Production Porcine é des Élevages Indusiriels \\ I7, avenue de Cucillé, 35000 Rennes (France) \\ * E.D.E. des Cótes-du-Nord, I, rue Voltaive, 2zoof Saint-Brieuc (France)
}

Attention paid to the post-weaning period of pigs intended for slaughter has been growing the last ten years. The present study was made in 2 groups of farms: group $A$ including 17 farms among which I $_{4}$ were rearing farms almost all using a conventional management system and group $B$ ( 9 farms), all rearing-fattening farms among which some practised very well the batch system.

The results mainly concerned the weiglt and age variability and accordingly piglet growth during the post-weaning period. The performances of group $B$ exceeded those of group A (for example the daily mean gain was $397 \mathrm{~g}$ /d against 350). However, the differences between farms remained within the same range (a difference of $\mathrm{I} 00 \mathrm{~g}$ between the daily mean gains of the first and the last farms).

In some farms, especially rearing-fattening, but sometimes also rearing farms, the piglets were sold at the same weight, but at highly variable ages.

The population density in the piggeries very often differed from the preconized standards. The difficulty of establishing housing and management systems according to farm capacities and of defining objectively piglet quality by relating weight to age is emphasized.

V. 一 FEEDING

\section{Total protein requirement of the growing pig}

\author{
Y. HENRY \\ Station de Recherches sur l'Élevage des Porcs \\ I.N.R.A., C.N.R.Z., $7835^{\circ}$ Jouy-en-Josas (France)
}

A further trial was conducted on growing female Large White pigs between 20 and $50 \mathrm{~kg}$ live weight to study the minimum requirement for total protein in the conditions of an optimum dietary balance for essential amino acids. The animals were fed a maize - soybean meal diet according to a moderately restricted scale of feeding. The optimum level of balanced protein 